\title{
EFEKTIVITAS PROGRAM UPPKS SEBAGAI USAHA MENINGKATKAN KESEJAHTERAAN KELUARGA MELALUI USAHA EKONOMI: STUDI KASUS KELURAHAN SRIMARTANI, PIYUNGAN, BANTUL
}

\author{
Susianti \\ Akademi Manajemen Administrasi Dharmala Yogyakarta,email: Susianti.msc@gmail.com
}

\begin{abstract}
This study aims to determine and analyze the effectiveness and benefit of UPPKS program based on welfare after receiving UPPKS program assistance.Given the importance of improving welfare through family empowerment as a breakthrough to accelerate the transformation of non-socioeconomic activities into economic enterprises, it is hoped that through this research, families especially PreSejahtera and KS 1 are able to take advantage of existing business opportunities in the framework of learning productive economic enterprises at the household scale as a business improving family welfare, especially in Srimartani, Piyungan, Bantul. This research is quantitative with judgment sampling method through questionnaires and interviews on UPPKS Program beneficiaries.The effectiveness analysis of the UPPKS Program is done by comparing the realization of the average number of effectiveness of all indicator variables in both input, process and output. While the McNemar test is used to calculate the benefit of the program to the community that follows the UPPKS Program by looking at the significance of the changes.From the research result, it is found that the implementation of UPPKS Program in Srimartani, Piyungan, Bantul based on input, process and output indicator is very effective that is 83.33 percent.And the change in the welfare of respondents is significantly assessed from the aspect of income and working hours before and after following UPPKS Program.
\end{abstract}

Keywords:UPPKS Programs; effectiveness; economic enterprises; welfare

\begin{abstract}
Abstrak
Penelitian ini bertujuan untuk mengetahui dan menganalisis tingkat efektivitas dan manfaat program UPPKS berdasarkan kesejahteraan setelah menerima bantuan program UPPKS. Mengingat betapa pentingnya peningkatan kesejahteraan melalui pemberdayaan keluarga sebagai terobosan untuk mempercepat transformasi kegiatan nonsosial ekonomi menjadi usaha ekonomi maka diharapkan melalui penelitian ini, keluarga khususnya PraSejahtera dan KS 1 mampu memanfaatkan peluang usaha yang ada dalam rangka pembelajaran usaha ekonomi produktif pada skala rumah tangga sebagai usaha meningkatkan kesejahteraan keluarga terutama di Kelurahan Srimartani, Piyungan, Bantul. Penelitian ini bersifat kuantitatif dengan metode judgment sampling melalui kuesioner dan wawancara pada anggota penerima bantuan Program UPPKS. Analisis efektivitas Program UPPKS dilakukan dengan membandingkan realisasi jumlah rata-rata efektivitas dari seluruh indikator variabel baik input, proses dan output.SedangkanTes McNemar digunakan untuk menghitung manfaat program terhadap masyarakat yang mengikuti Program UPPKS dengan melihat nilai signifikasi perubahan.Dari hasil penelitian diperoleh bahwa pelaksanaan Program UPPKS di Kelurahan Srimartani, Piyungan, Bantul berdasarkan indikator variabel input, proses dan output tergolong sangat efektif yaitu sebesar 83,33 persen. Dan terjadi perubahan tingkat kesejahteraan responden secara signifikan dinilai dari aspek pendapatan dan jam kerja sebelum dan sesudah mengikuti Program UPPKS.
\end{abstract}

Kata Kunci: Program UPPKS; efektivitas; usaha ekonomi; kesejahteraan 


\section{PENDAHULUAN}

\subsection{Latar Belakang}

Badan Kependudukan dan Keluarga Berencana Nasional (BKKBN) merupakan salah satu institusi yang bertanggung jawab dalam hal pengendalian jumlah penduduk di Indonesia. Pemberdayaan keluarga di bidang ekonomi merupakan salah satu usaha yang dapat dilakukan untuk dapat meningkatkan potensi keluarga dalam hal kesejahteraan. Pelaksanaan program pemberdayaan ekonomi keluarga telah dikembangkan oleh BKKBN melalui Program Usaha Peningkatan Pendapatan Keluarga Sejahtera (UPPKS) yang dibentuk pada tahun 1994.

UPPKS sebenarnya sudah ada sejak tahun 1979 dengan nama UPPKA (Usaha Peningkatan Pendapatan Keluarga Akseptor). Berdasarkan data BKKBN Pusat cq. Direktorat Pemberdayaan Ekonomi Keluarga (DitPemKon) tahun 2012 jumlah seluruh anggota UPPKS secara nasional ada 1.210.941 anggota, dengan jumlah sebanyak 84.660 kelompok (BKKBN, 2012). Kebanyakan dari anggota kelompok UPPKS ini adalah perempuan. Ibu-ibu peserta program UPPKS ini memiliki kekhususan yaitu, meningkatkan kesejahteraan keluarga melalui pemberdayaan perempuan.

Usaha Peningkatan Pendapatan Keluarga Sejahtera yang kemudian disingkat menjadi UPPKS ini adalah program pemerintah untuk membantu keluarga miskin dalam meningkatkan pendapatan keluarga. Saat ini masih banyak keluarga yang menghadapi berbagai kendala dan hambatan untuk dapat hidup sejahtera dan berkualitas. Hal ini juga terjadi di Kelurahan Srimartani, Kecamatan

Piyungan, Kabupaten Bantul, Provinsi DI Yogyakarta. Masalah utama yang menjadi kendala terbesar dalam keluarga adalah peningkatan kesejahteraan. Kesejahteraan keluarga secara langsung berkaitan erat dengan masalah keuangan atau pendapatan keluarga. Hal ini disebabkan banyaknya kebutuhan keluarga yang harus dicukupi oleh orangtua terutama kepala keluarga, yang kemudian mengharuskan kepala keluarga bekerja keras untuk memenuhi kebutuhan keluarga tersebut.

Data dari BKK, PP, KB Bantul, dan Indriastuti pada tahun 2014 menunjukkan bahwa penduduk miskin Kabupaten Bantul periode tahun 2006-2011 kecenderungannya mengalami penurunan. Jumlah Kepala keluarga Miskin di Kecamatan Piyungan pada tahun 2011 berjumlah sebesar 2.257 KK dari total KK sebesar 13.998, sedangkan jumlah jiwa miskin dalam keluarga sebesar 6.921 jiwa dari total Jiwa sebesar 45.626 jiwa.

Berdasarkan Peraturan Bupati Bantul Nomor 18 Tahun 2013 tentang Petunjuk Teknis Operasional Tim Koordinasi Penanggulangan Kemiskinan Kabupaten Bantul, memuat lampiran yang berkaitan denganStrukturOrganisasiPelaksanaan
Penanggulangan Kemiskinan di Kabupaten Bantul yang memasukkan UPPKS sebagai salah satu kelompok masyarakat yang terkait dalam pelaksanaan penanggulangan kemiskinan di Kabupaten Bantul (lihat Gambar 1.1).

Gambar 1.1 Struktur Organisasi Pelaksanaan Penanggulangan Kemiskinan di Kabupaten Bantul

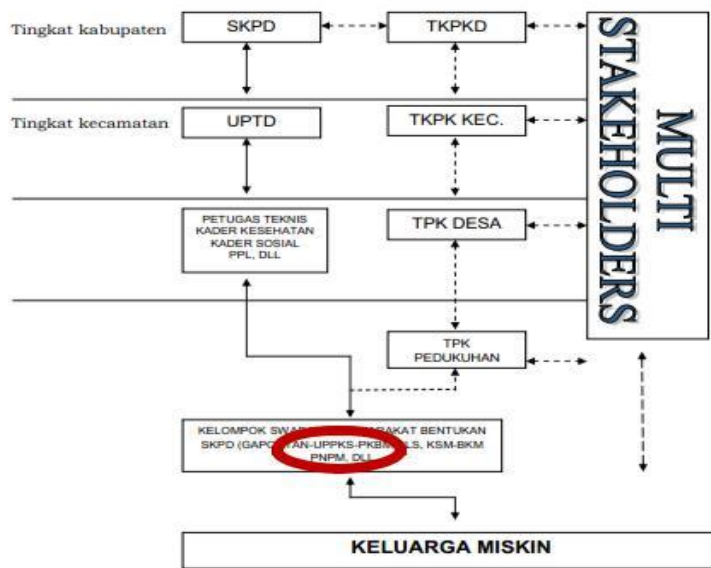

GARIS KOMANDO GARIS FASILITASI

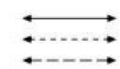

Sumber: Peraturan Bupati Bantul, 2013

Menurut Indriastuti (2014), berbagai upaya telah dikembangkan pemerintah untuk meningkatkan kualitas keluarga agar keluarga mampu mengembangkan prakarsa dan meningkatkan kesejahteraan. Hingga muncul program UPPKS yang merupakan tindak lanjut program Keluarga Berencana (KB) oleh Badan Kependudukan Keluarga Berencana Nasional (BKKBN).

Berdasarkan data BKKBN Tahun 2014 menunjukkan bahwa jumlah Kepala Keluarga berdasarkan Tahapan Keluarga Sejahtera. Di mana di Kabupaten Bantul jumlah KK untuk KPS, KS I dan KS II memiliki jumlah yang hampir sama banyaknya, yaitu masing-masing $43.192 \mathrm{KK}, 45.369 \mathrm{KK}$, dan 48.457 KK. Sedangkan untuk jumlah keanggotaan kelompok UPPKS di Kabupaten Bantul termasuk jumlah anggota UPPKS di Kecamatan Piyungan pada tahun 2012 ada 97 kelompok UPPKS dengan jumlah anggota 1.807 orang yang masing-masing mewakili satu keluarga (KK). Dari jumlah tersebut anggota perempuan sebesar 1.727 anggota, merupakan anggota perempuan terbanyak dari seluruh kelompok UPPKS di Kabupaten Bantul.

Peningkatan kesejahteraan melalui pemberdayaan keluarga merupakan terobosan untuk mempercepat transformasi kegiatan non sosial ekonomi menjadi usaha ekonomi. Pemberdayaan keluarga dibidang ekonomi bertujuan untuk menumbuhkan dan meningkatkan minat, semangat, dan keterampilan keluarga dalam bidang usaha 
Susianti, Efektifitas Program UPPKS sebagai usaha meningkatkan kesejahteraan...

ekonomi produktif. Melalui upaya ini, keluarga khususnya PraSejahtera dan Keluarga Sejahtaera 1 mampu memanfaatkan peluang usaha yang ada dalam rangka pembelajaran usaha ekonomi produktif pada skala rumah tangga.

Program UPPKS memiliki tujuan dimana membangun ketahanan ekonomi dan kemandirian keluarga serta masyarakat melalui kemampuan wanita dalam rangka mewujudkan keluarga kecil bahagia dam sejahtera. UPPKS merupakan wahana untuk menumbuh kembangkan usaha ekonomi produktif, sekaligus sebagai proses pembelajaran usaha ekonomi produktif (UEP) tersebut melalui dinamika kelompok usaha bersama, oleh karena itu disamping diperlukan pemahaman tentang manajerial juga aspek motivasi/kemampuan diri akan

mempengaruhi kepada keberhasilan dalam pengelolaan Poktan UPPKS.

Membangun kekuatan ekonomi melalui UEPUPPKS yaitu meliputi: pertama, Keterampilan adalah kemampuan praktis dibidang tertentu dalam melakukan suatu kegiatan yang menghasilkan barang/jasa yang diperoleh melalui proses pembelajaran. Kedua, Kewirausahaan adalah minat, semangat, sikap, perilaku, kemampuan seseorang untuk melakukan kegiatan UEP. Dan ketiga, Kemitrausahaan adalah Kerjasama usaha yang saling menguntungkan antara kelompok UPPKS dengan pengusaha kecil, menengah dan koperasi yang menyangkut permodalan, teknologi, produksi, pemasaran, pelatihan dan sebagainya.

\subsection{Perumusan Masalah}

Program peningkatan kesejahteraan keluarga melalui pendekatan kelompok UPPKS telah berlangsung cukup lama, selama itu pula mengalami pasang surut dalam pelaksanaannya. Di tengah pasang surut kegiatan UPPKS, peningkatan usaha ekonomi keluarga melalui kelompok UPKS merupakan salah satu bagian dari upaya penanggulangan kemiskinan yang telah dicanangkan pemerintah dengan sasaran pada kelompok keluarga miskin (Keluarga Pra Sejahtera, Keluarga Sejahtera I). Permasalahan yang masih dijumpai dari kegiatan UPPKS adalah kelangsungan kelompok, banyak usaha yang dilakukan oleh para anggota kelompok yang tidak berkembang secara baik. Dalam aspek permodalan, banyak kelompok yang belum mempunyai informasi lengkap tentang bentuk permodalan dan akses dari bantuan tersebut, kemampuan kelompok dalam mengelola modal.

Sedangkan permasalahan yang ada dalam pelaksanaan program UPPKS ini sejauh dapat terletak pada: tingkat pemahaman masyarakat (kaum perempuan) terhadap nilai-nilai pemberdayaan masih rendah, hal ini dapat dibuktikan dari kondisi jumlah Kepala Keluarga perempuan yang ada dan yang bekerja lebih sedikit dari Kepala Keluarga yang ada sehingga masih cukup banyak yang tidak mempunyai pekerjaan/ kegiatan dan bergantung pada suami, selain itu juga dukungan pemerintah terhadap upaya pemberdayaan perempuan masih rendah, sehingga tidak sedikit banyak perempuan yang lebih memilih berkiprah di tempat dan bidang yang jauh dari kompetensi yang dimilliki, dan banyak terjadi kasus rapuhnya ketahanan keluarga/rumah tangga sehingga diakhiri dengan perceraian sebagai akibat tuntutan kebutuhan ekonomi yang tidak terpenuhi, serta peran lintas sektor/stakeholder/petugas teknis masih kurang dalam menumbuh kembangkan kelompok kegiatan UPPKS.

\subsection{Pertanyaan Penelitian} yaitu:

Pertanyaan penelitian dalam penelitian ini

1. Bagaimana tingkat efektivitas program UPPKS yang dinilai dari perkembangan usaha ekonomi yang dikelola kelompok UPPKS di Kelurahan Srimartani, Kecamatan Piyungan, Bantul?

2. Bagaimana manfaat bantuan program UPPKS dilihat dari aspek pendapatan dan kesempatan kerja di Kelurahan Srimartani, Kecamatan Piyungan, Bantul?

\subsection{Tujuan Penelitian}

Penelitian ini bertujuan untuk mencoba menjawab pertanyaan di atas, yaitu:

1. Menganalisis tingkat efektivitas program UPPKS yang dinilai dari perkembangan usaha ekonomi yang dikelola kelompok UPPKS di Kelurahan Srimartani, Kecamatan Piyungan, Bantul.

2. Menganalisis manfaat bantuan program UPPKS dilihat dari sisi pendapatan dan kesempatan kerja di Kelurahan Srimartani, Kecamatan Piyungan, Kabupaten Bantul.

\subsection{Manfaat Penelitian}

Adapun manfaat dari penelitian ini adalah:

1. Mengembangkan IPTEK dan menambah wawasan penulis dalam bidang ekonomi pembangunan, khususnya yang berkaitan dengan usaha pemerintah untuk meningkatkan kesejahteraan keluarga melalui usaha ekonomi bagi masyarakat yang kurang mampu dalam pelaksanaan penanggulangan kemiskinan dengan program UPPKS.

2. Memberikan kontribusi masukan dan pemikiran untuk pembelajaran di kelas dalam menopang mata kuliah ekonomi pembangunan yang berkaitan dengan pembangunan ekonomi, khususnya dalam usaha peningkatan kesejahteraan masyarakat miskin melalui usaha ekonomi dengan Program UPPKS yang dikembangkan oleh BKKBN.

\subsection{Ruang Lingkup Penelitian}

Penelitian ini memiliki hal yang perlu diterangkan berkaitan dengan batasan-batasan yang digunakan dalam penelitian ini, yaitu: 
1. Penelitian ini khusus untuk mengetahui tingkat efektivitas program dan manfaat UPPKS yang dinilai dari perkembangan usaha ekonomi dikelola kelompok UPPKS.

2. Penelitian ini khusus melihat anggota masyarakat terutama ibu yang mengikuti program UPPKS.

3. Penelitian ini berfokus di Kelurahan Srimartani, Kecamatan Piyungan, Kabupaten Bantul. Hal ini berdasarkan dengan adanya bantuan program UPPKS yang diterima Kelurahan Srimartani, Kecamatan Piyungan dan banyaknya kelompok dan anggota UPPKS di Kelurahan Srimartani, Kecamatan Piyungan.

\subsection{Hipotesis Penelitian}

Berdasarkan tujuan penelitian, maka hipotesis dalam penelitian ini adalah:

H1: Pelaksanaan program UPPKS di Kelurahan Srimartani, Kecamatan Piyungan, Bantul berdasarkan indikator variabel input, proses dan output tergolong sangat efektif.

H2: Terjadi perubahan tingkat kesejahteraan responden secara signifikan pada saat sebelum dan sesudah mengikuti program UPPKS di Kelurahan Srimartani, Kecamatan Piyungan, Bantul.

\section{KAJIAN TEORI}

\subsection{Pembangunan Keluarga Sejahtera dan Kemiskinan}

Keluarga sejahtera adalah unit terkecil dari masyarakat yang terdiri dari suami, istri atau suami istri dengan anaknya (Sekretaris Menteri Negara Kependudukan/ BKKBN, 1994). Menurut BKKBN, keluarga sejahtera dapat dicapai melalui 5 tahapan, yaitu :

1. Keluarga Pra Sejahtera (KPS)

Keluarga Pra Sejahtera untuk kelompok keluarga miskin sekali. Kriteria KPS adalah keluarga yang tidak dapat melaksanakan ibadah menurut agama yang dianut, tidak mampu makan 2 kali sehari, tidak memiliki pakaian yang berbeda untuk di rumah, bekerja dan bepergian, bagian terluas rumah berlantai tanah dan tidak mampu membawa anggota keluarga untuk pergi ke sarana kesehatan.

2. Keluarga Sejahtera I (KS I)

KS I untuk kelompok keluarga miskin dengan kriteria: paling kurang seminggu sekali makan daging, ikan atau telur, setahun sekali seluruh anggota keluarga memperoleh paling kurang satu stel pakaian baru, laus lantai rumah keluarga paling kurang $8 \mathrm{~m}^{2}$ untuk tiap penghuni.

3. Keluarga Sejahtera II (KS II)

KPS II adalah keluarga yang dapat memenuhi kebutuhan dasar minimumnya, dapat pula memenuhi kebutuhan sosial psikologisnya, tetapi belum dapat memenuhi kebutuhan

pengembangannya.

4. Keluarga Sejahtera III (KS III)

KS III adalah keluarga yang telah dapat memenuhi kebutuhan dasar minimum, kebutuhan sosial psikologis, dan sekaligus dapat memenuhi kebutuhan pengembangannya, tetapi belum aktif menyumbangkan dan belum aktif dalam usaha kemasyarakatan dalam lingkungan desa atau wilayahnya.

5. Keluarga Sejahtera III Plus (KS III +)

KS III+ adalah keluarga yang telah dapat memenuhi kebutuhan dasar minimum, kebutuhan psikologis, kebutuhan pengembangan, sekaligus secara teratur ikut penyumbang dalam kegiatan sosial dan aktif pula mengikuti gerakan semacam itu.

Pembangunan keluarga sejahtera merupakan upaya menyeluruh dan terpadu yang dilakukan oleh pemerintah, masyarakat, dan keluarga untuk meningkatkan kualitas keluarga agar dapat meningkatkan fungsinya secara optimal (Heryendi, 2013).

Menurut Todaro (2000), secara umum, kemiskinan dapat diukur dengan kemiskinan absolut dan kemiskinan relatif. Tingkat pendapatan minimum cukup memenuhi kebutuhan fisik terhadap makanan, pakaian, dan perumahan untuk menjamin kelangsungan hidup adalah faktor yang menentukan kemiskinan absolut. Sedang kemiskinan relatif menurut Arsyad (1999), ditentukan oleh keadaan sekitar dibandingkan dengan lingkungan orang tersebut.

\subsection{Pendapatan}

Pendapatan adalah balas jasa yang diterima seseorang atas keikutsertaan dalam proses produksi barang dan jasa. Pendapatan ini merupakan pendapatan dari kerja. Sedangkan pendapatan yang diperoleh tidak dari kerja bisa berupa pemberian orang lain, pendapatan bunga uang, pendapatan dari usaha yang dijalankan orang lain, dan pendapatan bunga dan pendapatan persewaan kamar/rumah (Yasa, 2000).

\subsection{Modal Manusia}

Akumulasi modal manusia dapat mendorong peningkatan produktivitas dan pendapatan tenaga kerja serta membantu keluarga keluar dari lingkaran setan kemiskinan (Niken, 2010). Dan Indeks Pembangunan Manusia merupakan salah satu pencapaian pembangunan sumber daya manusia (Kintamani, 2008).

\subsection{Program UPPKS}

Program UPPKS merupakan program kelompok ekonomi produktif untuk meningkatkan pendapatan keluarga yang bertujuan untuk menciptakan keluarga kecil yang bahagia dan 
Susianti, Efektifitas Program UPPKS sebagai usaha meningkatkan kesejahteraan...

sejahtera, yang beranggotakan ibu-ibu/wanita dari golongan keluarga pra-KS, KS I, KS II, KS III dan $\mathrm{KS} \mathrm{III}^{+}$. Tahapan UPPKS terdiri dari tahapan dasar, berkembang dan mandiri. Pokok kegiatan yang dilakukan kelompok UPPKS meliputi: KIE (Komunikasi, Informasi, Edukasi), pendataan keluarga sejahtera, pembinaan usaha produktif dan kemitraan usaha (Heryendi,2013).

Berkaitan dengan program UPPKS menurut BKKBN (2009),Program Pemberdayaan Ekonomi Keluarga sebagai program beyond familyplanning bertujuan untuk meningkatkan kesejahteraan keluarga, khususnya peserta Keluarga Pra Sejahtera dan KS I. Program ini tertuang dalam Perpres No.7 tahun 2005 tentang RPJMN 2004-2009, mencakup sosialisasi kebutuhan dasar, akses sumberdaya ekonomi, capacity building, perluasan cakupan dan peningkatan kualitas usaha kelompok UPPKS.

Secara umum tujuan UPPKS adalah untuk meningkatkan usaha ekonomi produktif dan keterampilan terutama untuk keluarga akseptor KB yang tergabung dalam kegiatan kelompok UPPKS. Secara spesifik tujuan dibentuknya Program atau kelompok UPPKS yaitu: (Indriastuti, 2014)

1. Meningkatkan jumlah modal usaha yang dipinjamkan pemerintah melalui program UPPKS untuk pengembangan usaha kegiatan kelompok UPPKS.

2. Meningkatkan jumlah kelompok UPPKS yang memperoleh modal usaha.

3. Meningkatkan kualitas usaha kegiatan kelompok UPPKS.

4. Meningkatkan jumlah anggota kelompok UPPKS yang berwirausaha.

5. Meningkatkan pendapatan keluarga khususnya keluarga yang bergabung dalam kelompok UPPKS.

Manfaat dari program UPPKS sendiri adalah pendapatan keluarga meningkat, ketahanan ekonomi sekeluarga lebih mantap karena didukung sumber pendapatan yang tetap. Dengan adanya peningkatan pendapatan, maka kebutuhan dasar terpenuhi, anggota juga dapat memanfaatkan waktu luang untuk berkegiatan ekonomi dan memiliki tabungan guna menambahmodal usaha. Dengan begitu keluarga lebih bisa mandiri karena mampu mengenali dan memanfaatkan bakat dan kemampuan yang dimiliki, serta dalam hal keuangan atau ekonomi tidak tergantung pada orang lain. Hal ini dapat diketahui melalui kebiasaan hidup sehari-hari, seperti: apabila ada anggota keluarga yang sakit, biaya untuk ke dokter tersedia, serta mau dan mampu meningkatkan pengetahuan dan keterampilan diri. Banyak anak usia sekolah yang tidak putus sekolah, tingkat kesehatan keluarga meningkat, hal ini dibuktikan dengan jarangnya anggota keluarga sakit yang berarti ketahanan tubuh keluarga meningkat karena makanan dan gizi semakin terjamin. Manfaat untuk kelompok UPPKS nampak pada kebersamaan, kekeluargaan, gotong-royong, dan kepedulian sosial (BKKBN, 2014).

\subsection{Kelompok UPPKS}

Kelompok UPPKS merupakan unit binaan BKKBN di tingkat akar rumput untuk kegiatan pemberdayaan ekonomi keluarga sejak tahun 1979. Kelompok UPPKS adalah kelompok usaha produktif yang sebagian besar anggotanya adalah wanita dan ibu rumah tangga. Pada awalnya kelompok UPPKS adalah kelompok para peserta KB yang memiliki waktu luang kemudian memanfaatkan waktu luang tersebut dalam suatu kelompok kegiatan usaha kecil atau usaha rumahan untuk menambah penghasilan. Kelompok ini terus berkembang dalam bidang usaha maupun kelembagaan. Kelompok ini telah berkembang pada usaha yang berorientasi pada pasar dan dalam bidang kelembagaan, kelompok ini telah membuka diri memberikan kesempatan kepada simpatisan KB untuk bergabung melakukan suatu usaha ekonomi produktif, bahkan memberikan kesempatan kepada KPS dan KS I untuk belajar melakukan usaha (Indriastuti, 2014).

\subsection{Efektivitas Program UPPKS}

Menurut BKK, PP dan KB Kabupaten Bantul, konsep efektivitas Program UPPKS disini sebagai pencapaian hasil sesuai dengan tujuan UPPKS dan dengan sasaran yang tepat. Program UPPKS adalah program BKKBN yang diupayakan dalam rangka meningkatkan program KB pada keluarga miskin melalui bantuan modal usaha kepada kelompok UPPKS. Dimana program peningkatan pendapatan keluarga sejahtera ini telah berlangsung lebih dari tiga dekade. Selama itu pula upaya pengembangan usaha ekonomi keluarga mengalami pasang surut. Kadangkala fasilitas bantuan modal dan kemitraan begitu kuat, namun banyak ditemui permasalahan dalam kelompok UPPKS.

Efektivitas program UPPKS berkaitan erat dengan keberadaan kelompok UPPKS. Kelompok UPPKS akan berkembang jika ada peran aktif dari aktor-aktor dalam program UPPKS. Hal ini dijelaskan oleh Etzioni (dalam Kussriyanto, 1995) bahwa tujuan merupakan suatu keadaan di masa depan yang berusaha diwujudkan oleh organisasi dengan sumberdaya yang dimiliki ada agar hasil sesuai dengan apa yang akan dicapai. Selain itu dalam melakukan pencapaian tujuan, partisipasi aktif dari seluruh anggota organisasi sangat dibutuhkan.

\subsection{Kebijakan dan Akses Modal Program UPPKS}

Perkembangan kelompok UPPKS tidak hanya tergantung pada pengurus, tetapi juga dukungan dari instansi terkait, terutama dalam memberikan rekomendasi dan informasi untuk memperoleh pinjaman modal. Kelompok UPPKS perlu sumber modal yang cukup untuk menggerakkan roda usaha ekonomi. Banyaknya sumberr modal untuk kelompok UPPKS itu terkait peran aktif pemerintah melakukan usaha-usaha agar sumber modal tetap ada. Sumber 
modal tersebut antara lain: PD BPR Bank Bantul, Koperasi AKU DIY, Perum Pegadaian, APBD II dan sumber lainnya (Wibowo, 2002). Menurut BKK, PP dan $\mathrm{KB}$, mengenai sumber modal program UPPKS di Kabupaten Bantul, DIY, diperoleh dari APBN, APBD, Bank daerah, Kredit Usaha Rumah Tangga (KRISTA) merupakan produk PT. Pegadaian

(Persero), Program Nasional Pemberdayaan Masyarakat mandiri (PNPM Mandiri), Sumber lain seperti Pemberdayaan Ekonomi Masyarakat Miskin (PEKM), Kredit Kesejahteraan Keluarga (KESGA), Tabungan Keluarga Sejahtera (TAKESRA), Koperasi Asosiasi Kelompok UPPKS (KOP AKU), Kelompok Usaha Peningkatan Kesejahteraan (KUPK), SWADAYA.

Indriastuti (2014) menulis, Pemerintah perlu memberikan akses yang lebih besar kepada aset produksi yaitu akses modal bagi usaha rakyat, sehingga produksi, pendapatan, dan tabungan rakyat meningkat. Akses tersebut termasuk informasi, meski informasi akses akan diperoleh jika kelompok UPPKS aktif menggalinya. Kecakapan ketua kelompok dibutuhkan disini. Secara teoritis, modal usaha yang diperlukan setiap anggota masyarakat untuk meningkatkan produksi harus berasal dari kemampuan sendiri. Modal tersebut harus dihimpun dari tabungan yang diperoleh dari surplus pendapatan, setelah dikurangi untuk konsumsi jangka pendek. Tabungan yang dikumpulkan kemudian ditingkatkan menjadi investasi dan digunakan sebagai pembentukan modal. Dengan modal inilah produksi (kegiatan ekonomi) akan semakin meningkat. Ketersediaan modal untuk juga harus didukung adanya pembinaan, pelatihan, pengarahan, dan pengawasan oleh Petugas Lapangan Keluarga Berencana (PLKB) secara berkelanjutan.

\section{METODOLOGI PENELITIAN}

\subsection{Lokasi Penelitian}

Penelitian ini dilakukan di beberapa UPPKS di

Kelurahan Srimartani, Kecamatan Piyungan, Kabupaten Bantul. Hal ini dimaksudkan karena sumber data dalam penelitian ini berasal dari jawaban responden dari kuesioner dan data BKKBN berkaitan dengan jumlah peserta program UPPKS dan jumlah keluarga miskin pada masing-masing kelompok UPPKS yang ada di Kelurahan Srimartani, Kecamatan Piyungan. Pemilihan lokasi penelitian di Kelurahan Srimartani, Kecamatan Piyungan, dengan alasan pertama, karena Kelurahan Srimartani, Kecamatan Piyungan merupakan salah satu Kelurahan yang menerima bantuan program UPPKS dan memiliki sistem pengelolaan pelayanan yang baik di Kota Bantul.Kedua, Kelurahan Srimartani, Kecamatan Piyungan memiliki kelompok UPPKS yang sudah berkembang menjadi koperasi dan berbadan hukum.Sedangkan objek penelitian yang digunakan adalah anggota masyarakat terutama ibu yang mengikuti program UPPKS di Kelurahan Srimartani, Kecamatan Piyungan, Kabupaten Bantul yang dilaksanakan oleh BKKBN.

\subsection{Data dan Tehnik Pengumpulan Data}

Seperti halnya data terdiri dari data primer dan data sekunder, maka teknik pengumpulannya pun terdiri dari dua yaitu pengumpulan data primer, yaitu pengumpulan data secara langsung di lapangan oleh peneliti sendiri dan pengumpulan data sekunder, yaitu pengumpulan data tidak secara langsung di lapangan, data diperoleh dari pihak lain yang sudah mengumpulkannya terlebih dahulu. Dalam penelitian ini metode pengumpulan data menggunakan wawancara terstruktur, kuesioner, observasi dengan melakukan pengamatan dan wawancara mendalam terhadap responden. Selanjutnya, dilakukan pendekatan kuantitatif yang menggunakan metode survei. Adapun Jenis data yang digunakan meliputijenis usaha anggota, pendapatan anggota dan jumlah jam kerjayang mengikuti program UPPKS di Kelurahan Srimartani, Kecamatan Piyungan serta program Usaha Peningkatan Pendapatan Keluarga Sejahtera (UPPKS).

Sedangkan untuk mendapatkan data sekunder dilakukan dengan cara meneliti dokumen-dokumen yang sudah tersedia di berbagai instansi pemerintah, khususnya BKKBN. Hasil penelitiaan terdahulu dan beberapa hasil browsing di internet juga dilakukan sebagai data sekunder yang digunakan untuk perbandingan dan masukan dalam mengadakan analisis.

\subsection{Populasi dan Sampel}

Populasi dalam penelitian ini merupakan seluruh rumah tangga dalam kelompok UPPKS di Kelurahan Srimartani, Kecamatan Piyungan yang menerima bantuan program UPPKS. Kelompok UPPKS di Kelurahan Srimartani, Kecamatan Piyungan, Kabupaten Bantul meliputi kelompok UPPKS di Pedukuhan Kwasen, Daraman, Kembang Sari, Wanujoyo Lor, Wanujoyo Kidul, dan Mutihan. Dalam hal ini pemilihan sampel menggunakan judgmental sampling, yaitu tehnik pengambilan sampel berdasarkan judgment atau pertimbangan tertentu, dimana peneliti menggunakan pertimbangan tertentu dalam memilih anggota populasi sebagai sampel (Istijanto, 2006).

Penentuan jumlah sampel menggunakan jumlah kesalahan (error) yang ditoleransi yaitu sebesar 5 persen, dengan catatan sampel tersebut harus representatif atau mewakili populasi. Berdasarkan pertimbangan tersebut maka dalam menentukan jumlah sampel yang akan diteliti untuk menganalisis efektivitas program UPPKS menggunakan rumus formula Slovin (Sevilla et.al., 2007: 182), sebagai berikut: 
Susianti, Efektifitas Program UPPKS sebagai usaha meningkatkan kesejahteraan...

$$
=1+()^{2}
$$

Keterangan: $n=$ ukuran sampel, $N=$ ukuran populasi, $e=$ tingkat kesalahan $(5 \%)$.

Berdasarkan jumlah anggota dalam kelompok UPPKS yang ada di Kelurahan Srimartani kurang lebih adalah 350 orang maka sesuai dengan rumus di atas sampel yang diambil adalah 187 orang.

\subsection{Identifikasi Variabel Penelitian}

Dalam penelitian ini variabel yang digunakan dibedakan menjadi variabel input, variabel proses dan variabel output (Heryendi, 2013):

1. Varibel inputmerupakan variabel yang diamati untuk mengetahui ketepatan sasaran Program UPPKS bagi masyarakat di Kelurahan Srimartani, Kecamatan Piyungan yang meliputi sosialisasi petugas, bantuan sesuai kebutuhan, realisasi bantuan sesuai waktu, jumlah bantuan sesuai yang dijanjikan, dan bantuan sesuai dengan sasaran.

2. Variabel proses merupakan variabel yang diamati untuk mengetahui ketepatan sasaran Program UPPKS bagi masyarakat di Kelurahan Srimartani, Kecamatan Piyungan. Variabel ini diukur berdasarkan persepsi responden terhadap indikator proses yang terdiri dari Pembinaan/pelatihan/ pendampingan, kecepatan respon petugas terhadap keluhan, evaluasi/ monitoring dan pembinaan lanjutan.

3. Variabel output merupakan variabel yang diamati untuk mengetahui Program UPPKS dapat meningkatkan kesejahteraan keluarga, bantuan program UPPKS dapat meningkatkan pendapatan keluarga dan bantuan Program UPPKS dapat meningkatkan kesempatan kerja.

Adapun variabel input, proses dan output secara rinci dapat dilihat dalam Tabel 3.1 berikut ini:

Tabel 3.1 Varibel Input, Proses dan Output dalam Penelitian

\begin{tabular}{|c|c|}
\hline No. & Variabel \\
\hline 1. & $\begin{array}{l}\text { Input }\left(\mathrm{X}_{1}\right) \\
\text { Sosialisasi petugas }\left(\mathrm{X}_{1.1}\right) \\
\text { Bantuan sesuai kebutuhan }\left(\mathrm{X}_{1.2}\right) \\
\text { Realisasi bantuan sesuai waktu }\left(\mathrm{X}_{1.3}\right) \\
\text { Jumlah bantuan sesuai janji }\left(\mathrm{X}_{1.4}\right) \\
\text { Bantuan sesuai dengan sasaran }\left(\mathrm{X}_{1.5}\right)\end{array}$ \\
\hline 2. & $\begin{array}{l}\text { Proses }\left(\mathrm{X}_{2}\right) \\
\text { Pembinaan / pelatihan / pendampingan } \\
\quad\left(\mathrm{X}_{2.1}\right) \\
\text { Respon petugas cepat }\left(\mathrm{X}_{2.2}\right) \\
\text { Evaluasi/ monitoring }\left(\mathrm{X}_{2.3}\right) \\
\text { Pembinaan lanjutan }\left(\mathrm{X}_{2.4}\right)\end{array}$ \\
\hline
\end{tabular}

\begin{tabular}{|c|c|c|}
\hline 3. & $\begin{array}{l}\text { Output }\left(\mathrm{X}_{3}\right) \\
\text { Program meningkatkan } \\
\left(\mathrm{X}_{3.1}\right) \\
\text { Program meningkatkan } \\
\left(\mathrm{X}_{3.2}\right) \\
\text { Program meningkatkan } \\
\text { kerja }\left(\mathrm{X}_{3.3}\right)\end{array}$ & $\begin{array}{l}\text { kesejahteraan } \\
\text { pendapatan } \\
\text { kesempatan }\end{array}$ \\
\hline
\end{tabular}

Sumber: Heryendi, 2013

\subsection{Pengujian Instrumen Penelitian}

Pengujian instrumen penelitian menggunakan uji validitas dan uji reabilitas dimana instrumen yang dipakai dalam penelitian akan berfungsi baik apabila instrumen tersebut valid dan reliabel. Menurut Sudarmanto (2005), Uji validitas dilakukan dengan cara mengkolerasikan antar skor setiap instrumen dengan skor jumlah seluruh instrumen pernyataan. Syarat validitas harus memenuhi batas minimum yaitu $r=0,3$. Butir pernyataan dalam penelitian harus memiliki koefisien korelasi lebih besar dari 0,3 untuk memenuhi syarat validitas. Sedangkan reabilitas digunakan untuk mengetahui sejauh mana pengukuran itu memberikan hasil relatif tidak berbeda apabila dilakukan pengukuran ulang pada subyek yang sama. Reliabilitas menunjukkan konsistensi dan stabilitas dari skor (skala pengukuran). Suatu kuesioner dikatakan reliable atau handal apabila jawaban seseorang terhadap pertanyaan adalah konsisten atau stabil dari waktu ke waktu (Ghozali, 2011:47). Dan variabel dapat dikatakan reliabel jika nilai Cronbach Alpha lebih besar dari 0,70 (Nunnally, 1994).

\subsection{Analisis Statistik Deskriptif}

Menurut Supranto (2000), Penilaian responden mengenai variabel yang ditanyakan apakah sangat baik atau tidak, dapat diketahui dengan menggunakan lima skala pengukuran (penilaian) dengan kriteria:

$$
\begin{array}{rll}
\text { 1. } & 1,00-1,75=\text { sangat tidak baik } \\
\text { 2. } & 1,76-2,25 & =\text { tidak baik } \\
\text { 3. } & 2,26-3,25 & =\text { cukup baik } \\
\text { 4. } & 3,26-4,25 & =\text { baik } \\
\text { 5. } & 4,26-5,00 & =\text { sangat baik }
\end{array}
$$

\subsection{Efektivitas Program UPPKS}

Pengukuran efektivitas dilakukan dengan mengukur kesesuaian antara output dengan tujuan yang ditetapkan. Dimana tingkat efektifitas program menunjukkan kemampuan pemerintah daerah dalam mewujudkan program yang direncanakan dengan membandingkan terhadap target yang ditetapkan. Dan tingkat efektivitas ini dapat dievaluasi terkait dengan variabel input, proses dan output (Subagyo, 2000).

Dalam penelitian ini, analisis efektifitas program UPPKS dilakukan dengan membandingkan realisasi jumlah rata-rata efektivitas dari seluruh indikator variabel baik input, proses dan output 
dengan target 3 jenis indikator input, proses dan output. Adapun analisis matematika dan statistiknya sebagai berikut:

$=$ Jumlah rata - rata efektivitas seluruh indikator

\subsection{Tes McNemar}

Tes McNemar adalah uji statistik nonparametrik yang digunakan pada data nominal. Tes McNemar digunakan pada 2x2 tabel klasifikasi untuk mencari perbedaan antara dua proporsi yang berpasangan. Kasus yang sering digunakan pada Tes McNemar adalah kasus dengan desain before dan after. Dalam uji statistik McNemar, menggunakan koreksi Yates untuk mengambil keputusan menerima atau menolak Ho. Koreksi Yates dapat kita lihat dengan cara: jika $\mathrm{X}^{2}$ memberikan kesimpulan yang signifikan, maka kita harus menolak Ho dan menerima Ha dimana ada perbedaan yang signifikan diantara proporsi marjinal antara satu dengan yang lain.

Formula Tes McNemar sebagai berikut:

$$
\chi^{2}=\frac{\left[A-\left(\frac{A+D}{2}\right)\right]^{2}}{\frac{A+D}{2}}+\frac{\left[D-\left(\frac{A+D}{2}\right)\right]^{2}}{\frac{A+D}{2}}
$$

Dimana: $\chi^{2}=$ Nilai khai-kuadrat hasil perhitungan, $\mathrm{A}=$ Objek yang menampilkan perubahan jawaban dari positif menjadi negatif, $\mathrm{D}=$ Objek yang menampilkan perubahan jawaban dari negatif menjadi positif, 2 = konstanta

TesMcNemar digunakan untuk menghitung manfaat program terhadap masyarakat yang mengikuti program UPPKS dengan melihat nilai signifikasi perubahan (Siegel, 1994). Dalam hal ini persepsi responden terhadap manfaat kepada penerima bantuan program UPPKS dapat dilihat berdasarkan sisi pendapatan dan kesempatan kerja dengan menggunakan statistik non parametrik dengan Tes McNemar(Heryendi, 2013).

\section{HASIL DAN PEMBAHASAN}

\subsection{Gambaran Umum Daerah Penelitian}

Kelurahan Srimartani merupakan salah satu dari tiga kelurahan yang ada di Kecamatan Piyungan, Kabupaten Bantuldengan kode desa: 340214203 dan tahun pembentukan: 1947. Dipimpin oleh Kepala Desa yang memiliki 17 pedukuhan dan letak daerah berada di koordinat $-7.824737,110.479690$. Adapun 17 pedukuhan yang berada di wilayah administrasi Kelurahan Srimartani meliputi: Dusun Mandungan, Piyungan, Pos Piyungan, Wanujoyo Lor, Wanujoyo Kidul, Munggur, Mutihan, Daraman, Kwasen, Mojosari, Kembangsari, Petir, Sanansari, Bulusari,
Rejosari Kemloko, Umbulsari. Jumlah keseluruhan penduduk Desa Srimartani, Kecamatan Piyungan menurut jenis kelamin pada Semester I 2016 sebesar 16.275 orang dengan jumlah penduduk laki-laki sebesar 8.236 orang dan penduduk perempuan sebesar 8.039 orang. Sebagian besar penduduk Desa Srimartani adalah Petani.

Produk pertanian Desa Srimartani sangat beraneka ragam mulai dari tanaman pangan (padi), sayuran, buah-buahan, empon-empon, dan lain-lain namun sebagian besar produk pertanian desa ini dijual dalam bentuk bahan mentah. Sehingga hal ini menjadikan desa ini memiliki potensi dalam pengembangan teknologi pasca panen dan pengolahan hasil produk pertanian lokal, serta peningkatan produktivitas usaha tani dan ternak melalui pengembangan usaha tani terpadu (Integrated Farming System).

Dengan memiliki visi, terbentuknya pemerintahan desa yang bersih dan berwibawa untuk mewujudkan kehidupan masyarakat Desa Srimartani yang sejahtera lahir dan batin maka dirumuskan misi Desa Srimartani yang tertuang dalam RPJMDes 2013-2017. Misi ini terdiri dari 5 rumusan, yaitu:

1. Mewujudkan desa yang sehat dan bersih lahir dan batin dalam setiap bidang kehidupan sebagai bentuk peribadatan kepada Tuhan Yang Maha Esa.

2. Meningkatkan kesejahteraan dan taraf hidup masyarakat yang bertumpu pada keadilan dan kejujuran sehingga menebarkan kebarokan.

3. Meningkatkan kualitas pelayanan kepada masyarakat dengan jalan melakukan penyehatan dan penyederhanaan prosedur birokrasi.

4. Melakuka sinergi program pembangunan yang terpadu dan berkesinambungan dalam segala hal apapun/fisik dan non fisik.

5. Membangun dan memperkuat kemandirian masyarakat menuju masyarakat yang sejahtera fisik dan non fisik.

\subsection{Analisis Data Kualitatif}

Analisis data kualitatif dalam penelitian ini dilakukan dengan mengelompokkan responden berdasarkan karakteristik sebagai berikut:

1. Karakteristik Responden MenurutStatus Pasangan Usia Subur (PUS)

Dalam penelitian ini, pengelompokkan kategori Status Pasangan Usia Subur (PUS) dibagi menjadi 2 kategori. Karakteristik responden berdasarkan status Pasangan Usia Subur (PUS) disajikan dalam Tabel 4.1 berikut ini:

Tabel 4.1 Karakteristik Responden Berdasarkan Status PUS

\begin{tabular}{|c|c|c|c|}
\hline No & Usia & $\begin{array}{c}\text { Jumlah } \\
\text { Responden }\end{array}$ & $\begin{array}{c}\text { Persentase } \\
(\boldsymbol{\%})\end{array}$ \\
\hline 1 & Pasangan Usia & 126 & 67,38 \\
\hline
\end{tabular}


Susianti, Efektifitas Program UPPKS sebagai usaha meningkatkan kesejahteraan...

\begin{tabular}{|l|l|c|c|}
\hline & Subur & & \\
\hline 2 & $\begin{array}{l}\text { Bukan } \\
\text { Pasangan Usia } \\
\text { Subur }\end{array}$ & 61 & 32,62 \\
\hline Jumlah Responden & 187 & 100 \\
\hline
\end{tabular}

Sumber:Diolah dari data primer, 2016

Tabel 4.1 menunjukkan bahwa sebagian besar responden yang menjadi anggota UPPKS di Desa Srimartani merupakan kategori Pasangan Usia Subur (PUS) yaitu sebesar 126 responden atau 67,38 persen, Dalam Tabel 4.1 juga terlihat bahwa responden yang bukan Pasangan Usia Subur (PUS) memiliki jumlah responden yang cukup banyak (32,62 persen), ini menunjukkan kalau responden bukan Pasangan Usia Subur juga berperan dalam memanfaatkan usaha ekonomi dengan program UPPKS untuk meningkatkan kesejahteraan di Desa Srimartani, Piyungan, Bantul.

2. Karakteristik Responden Menurut Jenis Usaha

Dalam penelitian ini, peneliti mengelompokkan kategori jenis usaha menjadi 11 kategori. Karakteristik responden berdasarkan jenis usaha ini disajikan dalam Tabel 4.2 sebagai berikut:

Tabel 4.2 Karakteristik Responden berdasarkan Jenis Usaha

\begin{tabular}{|l|l|c|c|}
\hline $\begin{array}{c}\text { N } \\
\text { o }\end{array}$ & \multicolumn{1}{|c|}{ Jenis Usaha } & $\begin{array}{c}\text { Jumlah } \\
\text { Responden }\end{array}$ & $\begin{array}{c}\text { Persentase } \\
(\%)\end{array}$ \\
\hline 1 & Konveksi & 7 & 3,74 \\
\hline 2 & Kelontong & 24 & 12,83 \\
\hline 3 & Dagang & 73 & 39,04 \\
\hline 4 & Laundry & 2 & 1,07 \\
\hline 5 & Ternak & 25 & 13,37 \\
\hline 6 & Tani & 6 & 3,21 \\
\hline 7 & Katering & 6 & 3,21 \\
\hline 8 & Material & 2 & 1,07 \\
\hline 9 & Counter/Pulsa & 3 & 1,60 \\
\hline 10 & Warung & 6 & 3,21 \\
\hline & Makan/Angkringan & & 17,65 \\
\hline 11 & Lain-lain & 33 & 100 \\
\hline Jumlah Responden & 187 & \\
\hline
\end{tabular}

Sumber: Diolah dari data primer, 2016

Berdasarkan data pada Tabel 4.2 diketahui sebagian besar responden yang menjadi anggota UPPKS di Kelurahan Srimartani memiliki usaha dagang. Hal ini dilihat dari angka persentasenya sebesar39,04 persen dengan jumlah responden 73 orang. Jenis usaha produktif yang dikelola oleh anggota UPPKS cukup banyak variasinya. Tabel 4.2 di atas hanya menggolongkan ke dalam 10 kategori. Jenis usaha yang tidak termasuk dalam 10 kategori di atas, di masukkan ke dalam kategori jenis usaha lainlain. Adapun yang termasuk usaha lain-lain di antaranya adalah rental, LPK, bubur ayam, jasa gypsum, bumbon, bengkel dan tambal ban, wedang uwoh, obat herbal, air mineral, jual sprei dan bantal, keramik, es jus, dan fotocopy. Dan jenis usaha lainlain ini cukup besar persentasenye yaitu 17,65 persen dibandingkan ternak, kelontong, ataupun tani dengan 33 responden. Kondisi ini menunjukkan bahwa selain dagang (39,04 persen), kelontong (12,83 persen) ataupun ternak $(13,37)$, usaha ekonomi lain-lain (17,65 persen) mempunyai potensi untuk bisa dikembangkan denganprogram UPPKS sebagai pilihan.

3. Karakteristik Responden Menurut Jumlah Modal Pinjaman

Dalam penelitian ini, peneliti mengelompokkan kategori jumlah modal pinjaman menjadi 3 kategori. Karakteristik responden berdasarkan jumlah pinjaman ini disajikan dalam Tabel 4.3 berikut ini:

Tabel 4.3 Karakteristik Responden berdasarkan Jumlah Modal Pinjaman

\begin{tabular}{|c|c|c|c|}
\hline No & $\begin{array}{c}\text { Jumlah Modal } \\
\text { Pinjaman Saat Ini }\end{array}$ & $\begin{array}{c}\text { Jumlah } \\
\text { Responden }\end{array}$ & $\begin{array}{c}\text { Persntase } \\
(\%)\end{array}$ \\
\hline 1 & $<=$ Rp. 2.000 .000 & 46 & 24,60 \\
\hline 2 & $>$ Rp. 2.000 .000 & 117 & 62,57 \\
\hline 3 & $>=$ Rp. 5.000 .000 & 24 & 12,83 \\
\hline \multicolumn{2}{|c|}{ Jumlah Responden } & 187 & 100 \\
\hline
\end{tabular}

Sumber: Diolah dari data primer, 2016

Berdasarkan data pada Tabel 4.3 diketahui sebagian besar responden (117 responden)yang menjadi anggota UPPKS di Kelurahan Srimartani memilikiusaha dengan jumlah modal pinjaman berkisar antara Rp. 2.000.000 sampai kurang dari Rp. 5.000 .000 (62,57 persen). Sedangkan responden dengan jumlah modal pinjaman sampai $\mathrm{Rp}$. $2.000 .000 \quad(24,60$ persen $)$ menempati urutan selanjutnya yang terdiri dari 46 responden dan jumlah modal pinjaman lebih dari Rp. $5.000 .000(12,83$ persen) menempati urutan terakhir yang dimiliki oleh anggota UPPKS yang menjadi responden dengan responden sebanyak 24 orang.

4. Karakteristik Responden Menurut Tahapan KS

Dalam penelitian ini, pengelompokkan kategori tahapan keluarga sejahtera dibagi menjadi 2 kategori. Adapun karakteristik responden menurut Tahapan Keluarga Sejahtera (KS) disajikan dalam Tabel 4.4 berikut ini:

Tabel 4.4 Karakteristik Responden berdasarkan Tahapan KS

\begin{tabular}{|c|l|c|c|}
\hline No & Pendapatan & $\begin{array}{c}\text { Jumlah } \\
\text { Responden }\end{array}$ & $\begin{array}{c}\text { Persentase } \\
(\mathbf{\%})\end{array}$ \\
\hline 1 & KPS \& KS I & 72 & 38,50 \\
\hline 2 & $\begin{array}{l}\text { KS II, III, \& } \\
\text { III+ }\end{array}$ & 115 & 61,50 \\
\hline \multicolumn{2}{|c|}{ Jumlah Responden } & 187 & 100 \\
\hline
\end{tabular}

Sumber: Diolah dari data primer, 2016

Tabel 4.4 menunjukkan persentaseTahapan KS responden yang bervariasi.Responden yang tahapan KSdengan tahapan KS II, III, \& III+ paling besar dengan persentase sebesar 61,50 persen. Sedangkan 38,50 persen merupakan responden dengantahapan 
KPS \& KS I. Kedua segmen ini mewakili karakteristik responden anggota UPPKS yang mengikuti dan menggunakan program UPPKS sebagai salah satu usaha untuk meningkatkan kesejahteraan keluarga melalui usaha ekonomi di Kelurahan Srimartani.

\subsection{Analisis Data Kuantitatif}

\subsubsection{Analisis Validitas dan Reliabilitas}

Analisis ini digunakan untuk mengukur konsistensi dalam pengukuran instrument penelitian yang digunakan yaitu terhadap butir-butir pertanyaan yang terdapat dalam kuesioner penelitian.

\section{a. Uji Validitas}

Uji validitas diperlukan untuk menguji sah atau valid tidaknya suatu kuesioner, dalam hal ini digunakan rumus korelasi product moment. Suatu kuesioner dikatakan valid apabila pertanyaan pada kuesioner mampu mengungkapkan sesuatu yang akan diukur oleh kuesioner tersebut (Ghozali, 2011:52).

Tabel 4.5 Hasil Uji Validitas Variabel Input ( )

\begin{tabular}{|c|c|c|l|c|}
\hline No & $\begin{array}{c}r \\
\text { hitung }\end{array}$ & $\begin{array}{c}r \text { tabel } \\
(5 \%) \\
d f=185\end{array}$ & Hasil Pengujian & $\begin{array}{c}\text { Kesim } \\
\text { pulan }\end{array}$ \\
\hline 1 & 0,719 & 0,1207 & $r$ hitung $>r$ tabel & Valid \\
2 & 0,745 & 0,1207 & $r$ hitung $>r$ tabel & Valid \\
3 & 0,776 & 0,1207 & $r$ hitung $>r$ tabel & Valid \\
4 & 0,678 & 0,1207 & $r$ hitung $>r$ tabel & Valid \\
5 & 0,675 & 0,1207 & $r$ hitung $>r$ tabel & Valid \\
\hline
\end{tabular}

Sumber: Diolah dari data primer, 2016

Hasil pengujian validitas instrumen dengan menggunakan taraf signifikansi sebesar 5 persen $(\alpha=$ 0,05 ) dapat dilihat pada Tabel 4.5, yang menunjukkan bahwa indikator variabelinput semuanya dinyatakan valid, tidak ada pertanyaan yang gugur. Korelasi hasil perhitungan ( ) positif dan lebih besar daripada $r$ tabel $(5 \%, d f=185)=0,1207$. Derajat kebebasan diperoleh dari rumus $d f=\mathrm{n}-2$ sehingga didapat $d f=187-2=185$.

Tabel 4.6 Hasil Uji Validitas Variabel Proses ( ）

\begin{tabular}{|c|c|c|c|c|}
\hline No & $\begin{array}{c}r \\
\text { hitung }\end{array}$ & $\begin{array}{c}r \text { tabel } \\
(5 \%) \\
d f=168\end{array}$ & Hasil Pengujian & $\begin{array}{c}\text { Kesim } \\
\text { pulan }\end{array}$ \\
\hline 1 & 0,856 & 0,1207 & $r$ hitung $>r$ tabel & Valid \\
2 & 0,817 & 0,1207 & $r$ hitung $>r$ tabel & Valid \\
3 & 0,895 & 0,1207 & $r$ hitung $>r$ tabel & Valid \\
4 & 0,817 & 0,1207 & $r$ hitung $>r$ tabel & Valid \\
\hline
\end{tabular}

Sumber: Diolah dari data primer, 2016

Hasil pengujian validitas instrumen dengan menggunakan taraf signifikansi sebesar 5 persen $(\alpha=$ 0,05 ) dapat dilihat pada Tabel 4.6, yang menunjukkan bahwa indikator variabel prosessemuanya dinyatakan valid, tidak ada pertanyaan yang gugur. Korelasi hasil perhitungan ( ) positif dan lebih besar daripada $r$ tabel $(5 \%, d f=185)=0,1207$. Derajat kebebasan diperoleh dari rumus $d f=\mathrm{n}-2$ sehingga didapat $d f=187-2=185$.

Tabel4.7 Hasil Uji Validitas Variabel Output ( )

\begin{tabular}{|c|c|c|l|c|}
\hline No & $\begin{array}{c}r \\
\text { hitung }\end{array}$ & $\begin{array}{c}r \text { tabel } \\
(5 \%) \\
d f=168\end{array}$ & Hasil Pengujian & $\begin{array}{c}\text { Kesim } \\
\text { pulan }\end{array}$ \\
\hline 1 & 0,923 & 0,1207 & $r$ hitung $>r$ tabel & Valid \\
2 & 0,926 & 0,1207 & $r$ hitung $>r$ tabel & Valid \\
3 & 0,768 & 0,1207 & $r$ hitung $>r$ tabel & Valid \\
\hline
\end{tabular}

Sumber: Diolah dari data primer, 2016

Hasil pengujian validitas instrumen dengan menggunakan taraf signifikansi sebesar 5 persen $(\alpha=$ 0,05) dapat dilihat pada Tabel 4.7, yang menunjukkan bahwa indikator variabel outputsemuanya dinyatakan valid, tidak ada pertanyaan yang gugur. Korelasi hasil perhitungan ( ) positif dan lebih besar daripada $r$ tabel $(5 \%, d f=185)=0,1207$. Derajat kebebasan diperoleh dari rumus $d f=\mathrm{n}-2$ sehingga didapat $d f=187-2=185$.

\section{b. Uji Reliabilitas}

Uji Reliabilitas digunakan untuk mengukur konsistensi dalam pengukuran instrument penelitian yaitu terhadap daftar pertanyaan (kuesioner). Reliabilitas akan menunjukkan sejauh mana pengukuran tersebut tidak menunjukkan hasil yang berbeda, apabila dilakukan pengukuran kembali terhadap subyek dalam kondisi yang sama. Suatu konstruk atau variabel dikatakan reliabel jika memberikan nilai Cronbach's Alpha> 0,70 (Nunnally, 1994).

\section{Tabel 4.8 Hasil Uji Reliabilitas}

\begin{tabular}{|c|c|c|c|c|c|}
\hline No & $\begin{array}{c}\text { Varia } \\
\text { bel }\end{array}$ & $\begin{array}{c}\text { Cronbach' } \\
\text { s Alpha }\end{array}$ & $\begin{array}{c}\text { Krite } \\
\text { ria } \\
\text { Nun } \\
\text { nally }\end{array}$ & $\begin{array}{c}\text { Hasil } \\
\text { Pengujian }\end{array}$ & $\begin{array}{c}\text { Kesimpu } \\
\text { lan }\end{array}$ \\
\hline 1 & $\begin{array}{l}\text { Input } \\
\left(\mathrm{X}_{1}\right)\end{array}$ & 0,754 & 0,70 & $\begin{array}{c}\text { Cronbach' } \\
\text { s Alpha > } \\
0,70\end{array}$ & Reliabel \\
\hline 2 & $\begin{array}{l}\text { Proses } \\
\left(\mathrm{X}_{2}\right)\end{array}$ & 0,867 & 0,70 & $\begin{array}{c}\text { Cronbach } \\
\text { s Alpha > } \\
0,70\end{array}$ & Reliabel \\
\hline 3 & $\begin{array}{l}\text { Output } \\
\left(\mathrm{X}_{3}\right)\end{array}$ & 0,846 & 0,70 & $\begin{array}{c}\text { Cronbach } \\
\text { s Alpha > } \\
0,70\end{array}$ & Reliabel \\
\hline \multicolumn{6}{|c|}{ Sumber: Diolah dari data primer, 2016} \\
\hline
\end{tabular}

\subsubsection{Analisis Efektivitas Program UPPKS}


Susianti, Efektifitas Program UPPKS sebagai usaha meningkatkan kesejahteraan...

Tujuan dan standar kebijakan merupakan suatu ukuran terhadap suatu kegiatan, pekerjaan, ataupun tindakan yang dilaksanakan dan memiliki fokus terhadap hasil kerja yang diperoleh. Adapun dalam pelaksanaannya, kegiatan atau pekerjaan tersebut harus didukung oleh pengetahuan dan kemampuan yang dimiliki sehingga akan menghasilkan pekerjaan yang tepat waktu, memberikan pelayanan yang memuaskan dan menghasilkan pekerjaan yang

efektif. Efektivitas dapat diukur dengan memperhitungkan kesesuaian antara output yang dihasilkan dengan tujuan yang telah ditentukan. Dalam hal ini tingkat efektivitas program UPPKS menunjukkan adanya kemampuan pemerintah daerah untuk mewujudkan program yang telah direncanakan dengan membandingkan target yang ditetapkan sebelumnya. Menurut Subagyo (2000), tingkat efektivitas dapat dievaluasi terkait dengan variabel input, proses dan output.

Adapun hasil penilaian/tanggapan responden terhadap variabel input, proses dan output menunjukkan penilaian/tanggapan dari responden sebagai berikut:

1. Variabel input. Variabel ini merupakan variabel yang digunakan untuk mengamati dan mengetahui efektivitas program UPPKS bagi masyarakat di Kelurahan Srimartani diukur dari sosialiasi petugas $\left(\mathrm{X}_{1.1}\right)$, bantuan sesuai kebutuhan $\left(\mathrm{X}_{1.2}\right)$, realisasi bantuan sesuai waktu $\left(\mathrm{X}_{1.3}\right)$, jumlah bantuan sesuai janji $\left(\mathrm{X}_{1.4}\right)$ dan bantuan sesuai sasaran ( $\left.\mathrm{X}_{1.5}\right)$. Berdasarkan nilai rata-rata jawaban responden terhadap pernyataan variabel input, pernyataan yang berkaitan dengan realisasi bantuan program UPPKS yang diberikan sesuai dengan waktu yang dijanjikan $\left(\mathrm{X}_{1.3}\right)$ memiliki nilai sangat baik $(4,26)$. Sedangkan untuk pernyataan sosialiasi petugas $\left(\mathrm{X}_{1.1}\right)$, bantuan sesuai kebutuhan $\left(\mathrm{X}_{1.2}\right)$, jumlah bantuan sesuai janji $\left(\mathrm{X}_{1.4}\right)$ dan bantuan sesuai sasaran $\left(\mathrm{X}_{1.5}\right)$ memiliki nilai dengan kategori baik. Hal ini dilihat dari nilai ratarata masing-masing pernyataan berkisar antara 3,264,25 (lihat lampiran).

2. Variabel proses. Variabel proses ini merupakan variabel yang digunakan untuk mengamati dan mengetahui efektivitas program UPPKS bagi masyarakat di Kelurahan Srimartani diukur dari pembinaan/pelatihan dan pendampingan dari petugas $\left(\mathrm{X}_{2.1}\right)$, kecepatan respon dari petugas $\left(\mathrm{X}_{2.2}\right)$, adanya evaluasi/monitoring dari petugas $\left(\mathrm{X}_{2.3}\right)$ dan adanya pembinaan lanjutan $\left(\mathrm{X}_{2.4}\right)$. Berdasarkan nilai rata-rata jawaban responden terhadap pernyataan variabel proses, semua pernyataan memiliki nilai dengan kategori baik (berkisar antara 3,26-4,25). Besarnya maisng-masing nilai rata-rata tersebut adalah Pendampingan dari petugas $\left(\mathrm{X}_{2.1}\right)$ mempunyai nilai rata-rata 3,92, Kecepatan respon dari petugas $\left(\mathrm{X}_{2.2}\right)$ mempunyai nilai rata-rata 4,01, Adanya evaluasi/monitoring dari petugas $\left(\mathrm{X}_{2.3}\right)$ mempunyai nilai rata-rata 3,98 dan Adanya pembinaan lanjutan $\left(\mathrm{X}_{2.4}\right)$ memiliki nilai rata-rata 4,10 (lihat lampiran).
3. Variabel output. Variabel output ini digunakan untuk mengamati dan mengetahui efektivitas program UPPKS bagi masyarakat di Kelurahan Srimartani

diukur dari keberhasilan program dalam meningkatkan kesejahteraan ( $\left.\mathrm{X}_{3.1}\right)$, meningkatkan pendapatan $\left(\mathrm{X}_{3.2}\right)$ dan meningkatkan kesempatan kerja anggota UPPKS ( $\left.\mathrm{X}_{3.3}\right)$ di Kelurahan Srimartani, Piyungan, Bantul. Berdasarkan nilai rata-rata jawaban responden terhadap pernyataan variabel output, pernyataan yang berkaitan dengan Keberhasilan program dalam meningkatkan kesejahteraan $\left(\mathrm{X}_{3.1}\right)$, dan Meningkatkan pendapatan $\left(\mathrm{X}_{3.2}\right)$ memiliki nilai dengan kategori sangat baik (4,37). Sedangkan untuk pernyataan Meningkatkan kesempatan kerja anggota UPPKS (X3.3) memiliki nilai dengan kategori baik. Hal ini dilihat dari nilai rata-rata penyataannya sebesar 4,20 (lihat lampiran).

Secara keseluruhan, berdasarkan uraiandi atas menunjukkan bahwa hasil penilaian/tanggapan responden terhadap pernyataan dalam variabel input, proses dan output memberikan nilai rata-rata yang memenuhi skala pengukuran dengan kriteria baik $(3,26-4,25)$ dan sangat baik $(4,26-5,00)$.

Dalam tahapan selanjutnya penelitian ini, analisis efektivitas program UPPKS dilakukan dengan cara membandingkan nilai realisasi (jumlah rata-rata efektivitas dari seluruh pernyataan dalam variabel input, proses dan output) dengan target (variabel input, proses dan output). Adapun hasil perhitungan efektivitas program UPPKS di Kelurahan Srimartani, Piyungan, Bantul ditunjukkan pada Tabel 4.9.

Hasil perhitungan yang ditunjukkan pada Tabel 4.9 menunjukkan nilai efektivitas program UPPKS sebesar 83,3 persen. Berdasarkan nilai ini dapat disimpulkan bahwa pelaksanaan Program UPPKS di Kelurahan Srimartani berdasarkan variabel input, variabel proses, dan variabel output adalah sangat efektif.

Tabel 4.9 Hasil Perhitungan Efektivitas Program UPPKS di Kelurahan Srimartani

\begin{tabular}{|c|c|c|c|c|}
\hline No & Variabel & $\begin{array}{c}\text { Efekt } \\
\text { ivitas } \\
(\%)\end{array}$ & $\begin{array}{c}\text { Rata- } \\
\text { rata } \\
(\%)\end{array}$ & $\begin{array}{c}\text { Efekti } \\
\text { vitas } \\
\text { Progr } \\
\text { am } \\
\end{array}$ \\
\hline 1 & Input $\left(X_{1}\right)$ & & & \multirow{9}{*}{83,33} \\
\hline & $\begin{array}{ll}\text { Sosialisasi } & \text { dari } \\
\text { petugas }\left(\mathrm{X}_{1.1}\right) & \\
\end{array}$ & 83,32 & \multirow{5}{*}{83,70} & \\
\hline & $\begin{array}{l}\text { Bantuan dari petugas } \\
\left(\mathrm{X}_{1.2)}\right.\end{array}$ & 82,78 & & \\
\hline & $\begin{array}{l}\text { Bantuan sesuai waktu } \\
\left(\mathrm{X}_{1.3)}\right.\end{array}$ & 85,13 & & \\
\hline & $\begin{array}{l}\text { Jumlah bantuan sesuai } \\
\text { janji }\left(X_{1.4}\right)\end{array}$ & 84,92 & & \\
\hline & $\begin{array}{l}\text { Bantuan sesuai dengan } \\
\text { sasaran }\left(X_{1.5}\right)\end{array}$ & 82,35 & & \\
\hline 2 & Proses $\left(\mathbf{X}_{2}\right)$ & & & \\
\hline & $\begin{array}{l}\text { Pembinaan/pelatihan/p } \\
\text { endampingan }\left(\mathrm{X}_{2.1}\right)\end{array}$ & 78,40 & \multirow[t]{2}{*}{80,05} & \\
\hline & Respon petugas cepat & 80,21 & & \\
\hline
\end{tabular}




\begin{tabular}{|c|c|c|c|}
\hline & $\left(\mathrm{X}_{2.2}\right)$ & & \\
\hline & $\begin{array}{l}\text { Evaluasi/monitoring } \\
\left(\mathrm{X}_{2.3}\right)\end{array}$ & 79,68 & \\
\hline & $\begin{array}{l}\text { Pembinaan lanjutan } \\
\left(\mathrm{X}_{2.4}\right)\end{array}$ & 81,93 & \\
\hline 3 & Output $\left(\mathrm{X}_{3}\right)$ & & \\
\hline & $\begin{array}{l}\text { Program dapat } \\
\text { meningkatkan } \\
\text { kesejahteraan }\left(\mathrm{X}_{3.1}\right)\end{array}$ & 87,38 & \multirow{3}{*}{86,24} \\
\hline & $\begin{array}{l}\text { Program dapat } \\
\text { meningkatkan } \\
\text { pendapatan }\left(\mathrm{X}_{3.2}\right) \\
\end{array}$ & 87,38 & \\
\hline & $\begin{array}{l}\text { Program dapat } \\
\text { meningkatkan } \\
\text { kesempatan kerja } \\
\left(\mathrm{X}_{3.3}\right)\end{array}$ & 83,96 & \\
\hline
\end{tabular}

Sumber: Diolah dari data primer, 2016

\subsubsection{Analisis Tes McNemar}

Tes McNemarmerupakan analisis statistik non parametrik yang digunakan untuk menghitung manfaat program terhadap masyarakat yang mengikuti program UPPKS dengan melihat nilai signifikansi perubahan. Dalam penelitian ini, Tes McNemar dilakukan dengan menilai persepsi responden terhadap manfaat bantuan program UPPKS berdasarkan aspek pendapatan dan aspek kesempatan kerja (jumlah jam kerja). Adapun hasil penilaian persepsi responden dapat dilihat pada Tabel 4.10 dan Tabel 4.11 berikut ini:

\section{Tabel4.10 Jam Kerja Responden pada Tes} McNemar

\begin{tabular}{|c|c|c|}
\hline $\begin{array}{c}\text { Jam Kerja } \\
\text { Responden Sebelum } \\
\text { Mengikuti Program } \\
\text { UPPKS }\end{array}$ & \multicolumn{2}{|c|}{$\begin{array}{c}\text { Jam Kerja Responden } \\
\text { Sesudah Mengikuti Program } \\
\text { UPPKS }\end{array}$} \\
\cline { 2 - 3 } & 0 & 1 \\
\hline 0 & 15 & 69 \\
\hline 1 & 19 & 84 \\
\hline
\end{tabular}

Sumber: Diolah dari data primer, 2016

Tabel 4.10 di atas menunjukkan bahwa sebagian besar responden memiliki jam kerja di atas rata-rata (1) sebelum mengikuti program UPPKS dan tetap memiliki jam kerja di atas rata-rata (1) setelah mengikuti program UPPKS yaitu 84 responden. Adapun responden yang memiliki jam kerja di bawah rata-rata (0) sebelum mengikuti program UPPKS dan mengalami perubahan jam kerja menjadi di atas ratarata (1) setelah mengikuti program UPPKS sebanyak 69 responden. Sedangkan responden yang memiliki jam kerja di bawah rata-rata (0) baik yang sebelum mengikuti maupun setelah mengikuti program UPPKS sebanyak 15 responden. Dan sebanyak 19 responden yang mengalami perubahan jam kerja, dari yang jam kerja di atas rata-rata (1) sebelum mengikuti program UPPKS menjadi jam kerja di bawah rata-rata (0) setelah mengikuti program UPPKS. Adanya perubahan menurunnya jam kerja setelah mengikuti program UPPKS ini disebabkan karena faktor usia yang membuat menurunnya kemampuan (kesehatan) dari responden yang bersangkutan. Sehingga kondisi ini membatasi usaha mereka untuk bekerja dan berusaha mendapatkan penghasilan dalam memenuhi kebutuhan keluarga.

Tabel 4.11 Pendapatan Responden pada Tes McNemar

\begin{tabular}{|c|c|c|}
\hline $\begin{array}{c}\text { Pendapatan } \\
\text { Responden } \\
\text { Sebelum Mengikuti } \\
\text { Program UPPKS }\end{array}$ & $\begin{array}{c}\text { Pendapatan Responden } \\
\text { Sesudah Mengikuti Program } \\
\text { UPPKS }\end{array}$ \\
\cline { 2 - 3 } & 0 & 1 \\
\hline 0 & 22 & 111 \\
\hline 1 & 7 & 47 \\
\hline
\end{tabular}

Sumber: Diolah dari data primer, 2016

Berdasarkan data pada Tabel 4.11, secara berurutan terlihat bahwa sebagian besar responden mengalami perubahan pendapatan dari program UPPKS. Di mana sebanyak 111 responden yang pendapatan di bawah UMR (0) sebelum mengikuti program UPPKS menjadi pendapatan di atas UMR (1) setelah mengikuti program UPPKS. Selanjutnya, sebanyak 47 responden yang tidak mengalami perubahan pendapatan, tetap pendapatan di atas UMR (1) sebelum maupun setelah mengikuti program UPPKS. Kemudian, responden yang juga tidak mengalami perubahan pendapatan, tetap pendapatan di bawah UMR (0) sebelum dan sesudah mengikuti program UPPKS sebanyak 22 responden. Sedangkan responden yang mengalami perubahan pendapatan dari pendapatan di atas UMR (1) sebelum mengikuti program UPPKS menjadi pendapatan di bawah UMR (0) sebanyak 7 responden. Adanya penurunan pendapatan setelah mengikuti program UPPKS ini salah satunya karena faktor usia dari responden yang membuat responden bersangkutan mengurangi waktu untuk mengembangkan usaha atau bekerja dengan alasan kemampuan yang sudah terbatas atau kesehatan yang mulai menurun.

Selanjutnya, Tes McNemar dilakukan dengan langkah-langkah sebagai berikut:

- Menentukan hipotesis:

$\mathrm{H}_{0}$ : Pendapatan anggota UPPKS sebelum dan sesudah mengikuti program UPPKS adalah sama.

Ha : Pendapatan anggota UPPKS sebelum dan sesudah mengikuti program UPPKS adalah tidak sama.

- Kriteria pengambilan keputusan:

a. Jika probabilitas (Asymp.Sig) $>0,05$, maka $\mathrm{H}_{0}$ diterima dan Ha ditolak

b. Jika probabilitas (Asymp.Sig) $<0,05$, maka $\mathrm{H}_{0}$ ditolak dan Ha diterima

Tabel4.12 Hasil Tes McNemar 
Susianti, Efektifitas Program UPPKS sebagai usaha meningkatkan kesejahteraan...

\begin{tabular}{|c|c|c|}
\hline & $\begin{array}{c}\text { Sebelum dan } \\
\text { Sesudah } \\
\text { Mengikuti } \\
\text { Program UPPKS }\end{array}$ & $\begin{array}{c}\text { Sebelum dan } \\
\text { Sesudah } \\
\text { Mengikuti } \\
\text { Program UPPKS }\end{array}$ \\
\hline $\mathrm{N}$ & 187 & 187 \\
\hline $\begin{array}{c}\text { Chi- } \\
\text { Square }\end{array}$ & 27,284 & 89,907 \\
\hline Asymp. Sig & 0,000 & 0,000 \\
\hline
\end{tabular}

Sumber: Diolah dari data primer, 2016

Hasil Tes McNemar pada Tabel 4.12 menunjukkan bahwa dari jumlah 187 responden didapat nilai probabilitas (Asymp. Sig) sebesar 0,000 untuk jam kerja maupun pendapatan. Nilai ChiSquare untuk jam kerja sebesar 27,284 dan pendapatan sebesar 89,907. Dari hasil tersebut pada nilai Asymp.Sig terlihat bahwa nilai probabilitas 0,000 , nilai ini lebih kecil dari $\alpha=0,05$. Maka $\mathrm{H}_{0}$ ditolak $(0,000<0,05)$. Dengan demikian keputusan yang diambil adalah menerima Ha, berarti jam kerja maupun pendapatan responden sebelum dan sesudah mengikuti program UPPKS adalah tidak sama. Dengan kata lain, program UPPKS memberi pengaruh terhadap jam kerja dan pendapatan responden. Hal ini menjelaskan bahwa terjadi perubahan tingkat kesejahteraan masyakarakat khususnnya anggota UPPKS secara signifikan pada saat sebelum dan sesudah mengikuti Program UPPKS dari aspek jam kerja dan pendapatan di Kelurahan Srimartani, Piyungan, Bantul.

\section{SIMPULAN DAN SARAN}

\subsection{Simpulan}

Dari hasil penelitian yang dilakukan dapat diperoleh beberapa kesimpulan yang dapat dikemukakan sebagai berikut:

1. Pelaksanaan Program UPPKS di Kelurahan Srimartani, Kecamatan Piyungan, Bantul berdasarkan indikator variabel input, proses dan output tergolong sangat efektif dengan nilai ekfektivitas sebesar 83,33 persen. Hal ini dibuktikan dengan usaha ekonomi kelompok UPPKS yang masih berjalan dan berkembang. Bahkan ada kelompok yang telah berkembang menjadi koperasi. Keberadaan usaha ekonomi ini membuat perputaran modal lebih baik, dan akan memberikan keuntungan bagi anggota maupun kelompok jika anggota maupun kelompok lebih mengembangkan usahanya. Keberhasilan lain dari program UPPKS di Kelurahan Srimartani yaitu akses peminjaman modal yang berkelanjutan. Kondisi ini disebabkan kelompok mempunyai komitmen dan tingkat kesadaran yang tinggi dalam pengembalian pinjaman modal yang sebelumnya secara tertib dan penuh tanggungjawab.

2. Terjadi perubahan tingkat kesejahteraan masyarakat (anggota UPPKS) secara signifikan yang dinilai dari aspek jam kerja dan pendapatan pada saat sebelum dan sesudah mengikuti
Program UPPKS di Kelurahan Srimartani, Kecamatan Piyungan, Bantul. Hal ini ditunjukkan oleh nilai probabilitas atau Asymp.Sig $=0,000$ dari hasil Tes McNemar yang lebih kecil dibandingkan $\alpha=0,05$ baik dari jam kerja maupun pendapatan keluarga. Kondisi ini menjelaskan bahwa keluarga khususnya Keluarga PraSejahtera dan Keluarga Sejahtaera I mampu memanfaatkan peluang usaha yang ada dalam rangka pembelajaran usaha ekonomi produktif pada skala rumah tangga.

\subsection{Saran}

Berdasarkan hasil simpulan di atas maka ada beberapa hal yang dapat dipertimbangkan dan bermanfaat bagi perkembangan dan keberlanjutan Program UPPKS di Kelurahan Srimartani, Piyungan, Bantul, yaitu:

1. Berkaitan dengan sumber pinjaman modal, dalam memberikan pinjaman modal hendaknya

pemberi pinjaman lebih memperhatikan penentuan tingkat bunga pinjaman yang tidak begitu tinggi (pinjaman lunak). Karena program UPPKS ini sasaran utamanya adalah keluarga Pra Sejahtera, KS I, KS II dan KS III yang mempunyai keterbatasan dan rendah kemampuan dalam ekonomi maupun keterampilan. Karena masih banyak kelompok yang harus menyanggupi membayar angsuran dengan bunga yang cukup tinggi. Terkadang hal ini memberatkan anggota, terutama bagi anggota bukan PUS yang usianya sudah tidak muda lagi dan harus tetap menjalankan usahanya untuk memenuhi kebutuhan hidup sehari-hari.

2. Adanya program pelatihan untuk meningkatkan keterampilan dan pemasaran secara berkelanjutan. Program yang berkelanjutan ini diharapkan bisa mengatasi kendala rendahnya keterampilan dan pengetahuan pemasaran yang dimiliki oleh para anggota yang mayoritas keluarga Pra Sejahtera, KS I, KS II, dan KS III. Hal ini bisa dijadikan faktor penunjang berkembangnya usaha ekonomi produktif yang mereka kelola dari aspek selain modal dalam bentuk uang. Dengan begitu keluarga lebih bisa mandiri karena mampu mengenali dan memanfaatkan bakat dan kemampuan yang dimiliki, serta dalam hal keuangan atau ekonomi tidak tergantung pada orang lain.

3. Peran kelompok UPPKS dan program UPPKS dari BKKBN ini perlu ditingkatkan lagi dan mendapatkan perhatian serta pengembangan lebih serius dari pemerintah dalam rangka peningkatan kesejahteraan keluarga melalui usaha ekonomi yang dilakukan oleh keluarga Prasejahtera, KS I, KS II, maupun KS III untuk mencapai ketahanan ekonomi keluarganya.

Selain pihak-pihak dalam lingkungan pemerintah, keberhasilan pelaksanaan program UPPKS sangat tergantung juga dengan 
partisipasi aktif dari anggota kelompok UPPKS. Karena kelompok UPPKS merupakan sasaran utama dari program UPPKS. Sehingga, berhasil atau tidak program UPPKS untuk mencapai tujuannya tidak bisa lepas dari besar kecilnya keseriusan peran kelompok UPPKS dalam mengembangkan usaha ekonomi yang sudah dijalankan selain peran dari pihak lain dalam melakukan pembinaan, pelatihan dan pendampingan.

\section{DAFTAR PUSTAKA}

Arsyad, Lincolin, 1999. Ekonomi Pembangunan, Yogyakarta: Sekolah Tinggi Ilmu Ekonomi YKPN.

BKKBN Pusat, 1994. Peraturan Pemerintah RI No.21 tentang Penyelenggaraan Pembangunan Keluarga Sejahtera, Jakarta: Sekretaris Menteri Negara Kependudukan BKKBN.

BKKBN Pusat, 1998. Strategi Pengembangan Kelompok Usaha Peningkatan Pendapatan keluarga Sejahtera dalam Gerakan Pembangunan Keluarga Sejahtera, Edisi Kedua, Jakarta.

Ghozali, Imam., 2011. Aplikasi Analisis Multivariate Dengan Program IBM SPSS19, Semarang: Badan Penerbit Universitas Diponegoro.

Husein, Umar, 2000. Metode Penelitian untuk Skripsi dan Tesis Bisnis, Jakarta: PT RajaGrafindo Persada.

Heryendi W.T dan A.A. Istri Ngurah Marhaeni, 2013. 'Efektivitas Program Usaha Peningkatan Pendapatan Keluarga Sejahtera (UPPKS) di Kecamatan Denpasar Barat', Jurnal Ekonomi Kuantitatif Terapan, 6(2): 78-85.

Indriastuti, Ida Fatma, 2014. Efektivitas Program Usaha Peningkatan Pendapatan Keluarga Sejahtera (UPPKS) Kecamatan Jetis, Kabupaten Bantul, Provinsi Daerah Istimewa Yogyakarta, Skripsi, Fakultas Ilmu Sosial dan Politik, Yogyakarta: Universitas Gadjah Mada.

Istijanto, 2006. Riset Sumber Daya Manusia, Cara Praktis Mendeteksi Dimensi-dimensi Kerja Karyawan, Jakarta.
Kintamani, Ida, 2008. 'Analisis Indeks Pembangunan Manusia'. Jurnal Pendidikan dan Kebudayaan, 14(72): 421-37.

Kussriyanto, Bambang. 1995. Ikhtisar Studi Organisasi, Jakarta: PT. Gramedia Pustaka Utama.

Murjasa Yasa, I G W, 2000. Jam Kerja, Pendapatan, dan Pengeluaran Pekerja Migran di Daerah Wisata Kuta Bali, Tesis S-2 Program Pasca Sarjana UGM.

Niken,Sulistyowati, 2010. 'Dampak Investasi Pendidikan terhadap Perekonomian dan Kesejahteraan Masyarakat Kabupaten dan Kota di Jawa Tengah'. Jurnal Organisasi dan Manajemen, 6(2): 158-170.

Nunnally, J. dan Bernstein, IH, 1994. Psychometric Theory, New York: McGraw-Hill.

Sevilla, Consuelo G. et.al., 2007. Research Methods, Quezon City: Rex Printing Company.

Siegel, Sidney, 1994. Statistik Non Parametrik Untuk Ilmu-ilmu Sosial, Jakarta: PT. Gramedia.

Subagyo, Ahmad Wito, 2000. Efektivitas Program Penanggulangan Kemiskinan dalam Pemberdayaan Pedesaan, Yogyakarta: UGM.

Sumodiningrat, Gunawan, 2005. Peran Kelompok UPPKS Dalam Penanggulangan Kemiskinan dan Peningkatan Ekonomi Keluarga, Jakarta: BKKBN.

Supranto, J, 2000. Statistik, Teori dan Aplikasi, Edisi Keenam, Jilid 1, Jakarta: Erlangga.

Todaro, Michael P, 2000. Pembangunan Ekonomi di Dunia Ketiga, Jilid 1, Edisi Ketujuh, Jakarta: Erlangga.

Turgut, Ozkan, 2011, 'Marketing and Financial Aspects with Microcredit and Turkey Sample'. Journal of Modern Accounting and Auditing, 7(9): 1014-1021.

Vanaja, Menon. 2012. 'Women Participation: Paradoxes in Management of Small Scale Industries: Urban-Rural Disparities', International Journal of Business and Management, 7(1): 143-150.

Wibowo, P, dan Wawan Munawar, 2002. Studi Kredit Kecil Perkotaan di Kota Yogyakarta, Jakarta: Laporan Lapangan SMERU. 
Susianti, Efektifitas Program UPPKS sebagai usaha meningkatkan kesejahteraan...

\section{LAMPIRAN}

Deskripsi Jawaban Responden Untuk Variabel Input

\begin{tabular}{|c|c|c|c|c|c|c|c|c|c|c|c|c|}
\hline \multirow{3}{*}{ No } & \multirow{3}{*}{ Pernyataan } & \multicolumn{10}{|c|}{ Jawaban } & \multirow{3}{*}{$\frac{\text { Rata- }}{\text { rata }}$} \\
\hline & & \multicolumn{2}{|c|}{ SS } & \multicolumn{2}{|c|}{$\mathbf{S}$} & \multicolumn{2}{|c|}{$\mathbf{C}$} & \multicolumn{2}{|c|}{ TS } & \multicolumn{2}{|c|}{ STS } & \\
\hline & & Org & $\%$ & Org & $\%$ & Org & $\%$ & Org & $\%$ & Org & $\%$ & \\
\hline 1 & $\mathrm{X}_{1.1}$ & 40 & 21,39 & 139 & 74,33 & 7 & 3,74 & 1 & 0,54 & 0 & 0 & 4,17 \\
\hline 2 & $\mathrm{X}_{1.2}$ & 32 & 17,11 & 149 & 79,68 & 6 & 3,21 & 0 & 0 & 0 & 0 & 4,14 \\
\hline 3 & $\mathrm{X}_{1.3}$ & 53 & 28,34 & 129 & 68,98 & 5 & 2,67 & 0 & 0 & 0 & 0 & 4,26 \\
\hline 4 & $\mathrm{X}_{1.4}$ & 51 & 27,27 & 131 & 70,05 & 5 & 2,67 & 0 & 0 & 0 & 0 & 4,25 \\
\hline 5 & $X_{1.5}$ & 48 & 25,67 & 113 & 60,43 & 26 & 13,9 & 0 & 0 & 0 & 0 & 4,12 \\
\hline & & & & & & & & & & & & 4,19 \\
\hline
\end{tabular}

Deskripsi Jawaban Responden Untuk Variabel Proses

\begin{tabular}{|c|c|c|c|c|c|c|c|c|c|c|c|c|}
\hline \multirow{3}{*}{ No } & \multirow{3}{*}{ Pernyataan } & \multicolumn{10}{|c|}{ Jawaban } & \multirow{3}{*}{$\begin{array}{l}\text { Rata } \\
\text {-rata }\end{array}$} \\
\hline & & \multicolumn{2}{|c|}{ SS } & \multicolumn{2}{|c|}{$\mathbf{S}$} & \multicolumn{2}{|c|}{$\mathrm{C}$} & \multicolumn{2}{|c|}{ TS } & \multicolumn{2}{|c|}{ STS } & \\
\hline & & Org & $\%$ & Org & $\%$ & Org & $\%$ & Org & $\%$ & Org & $\%$ & \\
\hline 1 & $\mathrm{X}_{2.1}$ & 22 & 11,76 & 129 & 68,98 & 35 & 18,72 & 1 & 0,54 & 0 & 0 & 3,92 \\
\hline 2 & $\mathrm{X}_{2.2}$ & 35 & 18,72 & 119 & 63,64 & 33 & 17,65 & 0 & 0 & 0 & 0 & 4,01 \\
\hline 3 & $\mathrm{X}_{2.3}$ & 30 & 16,04 & 124 & 66,31 & 33 & 17,65 & 0 & 0 & 0 & 0 & 3,98 \\
\hline 4 & $\overline{X_{2.4}}$ & 43 & 22,99 & 119 & 63,64 & 25 & 13,37 & 0 & 0 & 0 & 0 & 4,10 \\
\hline \multicolumn{12}{|c|}{ Total Rata-rata } & 4,00 \\
\hline
\end{tabular}


Journal of Business Administration Volume 1, Nomor 2, September 2017, hlm. 280-295

Deskripsi Jawaban Responden Untuk Variabel Output

\begin{tabular}{|c|c|c|c|c|c|c|c|c|c|c|c|c|}
\hline \multirow{3}{*}{ No } & \multirow{3}{*}{ Pernyataan } & \multicolumn{10}{|c|}{ Jawaban } & \multirow{3}{*}{$\frac{\text { Rata }}{\text {-rata }}$} \\
\hline & & \multicolumn{2}{|c|}{ SS } & \multicolumn{2}{|c|}{$\mathbf{S}$} & \multicolumn{2}{|c|}{$\mathbf{C}$} & \multicolumn{2}{|c|}{ TS } & \multicolumn{2}{|c|}{ STS } & \\
\hline & & Org & $\%$ & Org & $\%$ & Org & $\%$ & Org & $\%$ & Org & $\%$ & \\
\hline 1 & $\mathrm{X}_{3.1}$ & 74 & 39,57 & 108 & 57,75 & 5 & 2,67 & 0 & 0 & 0 & 0 & 4,37 \\
\hline 2 & $\mathrm{X}_{3.2}$ & 70 & 37,43 & 116 & 62,03 & 1 & 0,54 & 0 & 0 & 0 & 0 & 4,37 \\
\hline 3 & $\mathrm{X}_{3.3}$ & 42 & 22,46 & 140 & 74,87 & 5 & 2,67 & 0 & 0 & 0 & 0 & 4,20 \\
\hline & & & & Tot: & ata-1 & & & & & & & 4,31 \\
\hline
\end{tabular}

